\title{
Clinical relevance of breast and gastric cancer-associated polymorphisms as potential susceptibility markers for oral clefts in the Brazilian population
}

Renato Assis Machado ${ }^{1 *}$, Edimilson Martins de Freitas², Sibele Nascimento de Aquino ${ }^{3}$, Daniella Reis B. Martelli², Mário Sérgio Oliveira Swerts ${ }^{4}$, Silvia Regina de Almeida Reis ${ }^{5}$, Darlene Camati Persuhn ${ }^{6}$, Helenara Salvati Bertolossi Moreira ${ }^{7}$ Verônica Oliveira Dias ${ }^{2}$, Ricardo D. Coletta ${ }^{1}$ and Hercílio Martelli-Júnior ${ }^{2,4}$

\begin{abstract}
Background: Epidemiological studies have indicated a higher incidence of breast and gastric cancer in patients with nonsyndromic cleft lip with or without cleft palate $(\mathrm{NSCL} \pm P)$ and their relatives, which can be based on similar genetic triggers segregated within family with $N S C L \pm P$.

Methods: This multicenter study evaluated the association of 9 single nucleotide polymorphisms (SNP) in AXIN2 and $\mathrm{CDH1}$, representing genes consistently altered in breast and gastric tumors, with $N S C L \pm P$ in 223 trios (father, mother and patient with NSCL $\pm P$ ) by transmission disequilibrium test (TDT).

Results: Our results showed that the minor A allele of rs7210356 ( $p=0.01)$ and the T-G-G-A-G haplotype formed by rs7591, rs7210356, rs4791171, rs11079571 and rs3923087 SNPs ( $p=0.03)$ in AXIN2 were significantly undertransmitted to patients with NSCL \pm P. In CDH1 gene, the C-G-A-A and A-G-A-G haplotypes composed by rs16260, rs9929218, rs7186053 and rs4783573 polymorphisms were respectively over-transmitted ( $p=0.01)$ and under-transmitted $(p=0.008)$ from parents to the children with NSCL $\pm P$.
\end{abstract}

Conclusions: The results suggest that polymorphic variants in AXIN2 and CDH1 may be associated with NSCL $\pm P$ susceptibility, and reinforce the putative link between cancer and oral clefts.

Keywords: Nonsyndromic cleft lip with or without cleft palate, Breast cancer, Gastric cancer, AXIN2, CDH1

\section{Background}

Oral clefts are the most common congenital craniofacial abnormalities in humans [1, 2]. About $70 \%$ of cases occur as a nonsyndromic form, and the remaining 30\% are associated with Mendelian disorders or chromosomal, teratogenic and sporadic conditions $[3,4]$. Nonsyndromic oral clefts are traditionally divided in cleft lip only (NSCLO), cleft lip and palate (NSCLP) and cleft palate only (NSCPO), however, as there are similarities in both epidemiologic features and embryologic timing for both NSCLO and NSCLP, they are considered

\footnotetext{
* Correspondence: renatoassismachado@yahoo.com.br

'Department of Oral Diagnosis, Dental School, State University of Campinas,

Piracicaba, São Paulo, Brazil

Full list of author information is available at the end of the article
}

variants of the same defect and grouped together to form the group cleft lip with or without cleft palate $(\mathrm{NSCL} \pm \mathrm{P})[5,6]$. Oral clefts affect approximately 1 in 500-2000 live births, with variable prevalence around the world, often attributed to ethnic and environmental differences. American and Asian populations have a high prevalence (1:500), populations from Europe have intermediate prevalence (1:1000) and the lowest prevalence is observed in Africans and their descendants (1:2500) [7]. Previous studies have revealed that NSCL $\pm \mathrm{P}$ etiology is dependent of interactions between environmental and genetic risk factors $[8,9]$. In fact, epidemiological studies and analysis of animal models have provided evidences of a putative participation of agrotoxics, cigarette smoking, consumption of alcohol and drugs, malnutrition and some 
viral infections in etiology of NSCL $\pm P[10,11]$. Genetic linkage and genome-wide association studies (GWAS) have described several genes and loci in association with NSCL $\pm \mathrm{P}$, including IRF6, VAX1, MSX1, FOXE1, MYH9, MAFB, ABCA4, BMP4, FGFR2, TGFA, TGFB3, MTHFR, GSTT1, PDGFC, FGF8, PVRL1, SUMO1, CRISPLD2 and the regions $8 \mathrm{q} 24$ and $17 \mathrm{q} 22[1,12,13]$.

Epidemiological studies have shown a high risk of oral clefts in families with cancer, while others have provided consistent data about increased risk of cancer in patients with oral cleft and their relatives [14-18]. This association has been explicated because specific cancers, including those of breast and stomach, and NSCL \pm P may share similar genetic etiology $[14,19-21]$. The Wingless/integrase-1 (WNT) signaling pathway is an evolutionarily conserved pathway with major roles in cell migration, cell polarity, cell fate determination and organogenesis during embryonic development, including orofacial morphogenesis [22-24], and aberrant expression of several WNT family members is common in cancers $[25,26]$. The canonical WNT signaling is mediated by the translocation of $\beta$-catenin to the nucleus, where it activates transcription of several factors regulating proliferation and differentiation, while noncanonical WNT signaling is $\beta$-catenin independent [27].

The axis inhibition protein 2 (AXIN2), a member of the WNT pathway, is associated with the development and progression of breast cancers [21, 28], and polymorphisms in AXIN2 are associated with increased risk for breast cancer in premenopausal women [29]. E-cadherin, encoded by the CDH1 (cadherin-1) gene, is a transmembrane glycoprotein playing a crucial role in maintaining cell-to-cell adhesion [30]. E-cadherin has been reported to be a tumor suppressor and to be downregulated in gastric cancer [31-33]. Germline CDH1 mutations confer an increased risk of developing both gastric and breast cancer [34]. Genetics studies revealed that polymorphic variants in AXIN2 and CDH1 are risk factors for NSCL $\pm \mathrm{P}$ and tooth agenesis [35-40]. In this study, we postulated that single nucleotide polymorphisms (SNP) in genes associated with breast and gastric pathogenesis (AXIN2 and $C D H 1)$ might be related to the risk of NSCL \pm P. Thus, we evaluated the association of 9 SNPs in $C D H 1$ and AXIN2 with the risk of NSCL $\pm \mathrm{P}$ using a family-based study design (case-parent trios). This design has the advantage of bypass problems with population stratification. Indeed, the main disadvantage of case-control studies, the most common approach in genetic studies, is unaccounted population admixture with a possible threat to the validity of the obtained results.

\section{Methods}

This study included samples from four Brazilian states: Minas Gerais state (Center for Rehabilitation of Craniofacial Anomalies, Dental School, University of José Rosário Vellano, Alfenas-MG), located in the Southeastern region of Brazil, Paraná state (Association of Carrier of Lip and Palate Cleft-APOFILAB, Cascavel-PR), in the Southern region, Paraíba state (University Hospital of Lauro Wanderley-HULW, João Pessoa-PB) and Bahia state (Santo Antonio Hospital, Salvador-BA), which are located in the Northeast region. The cohort was composed of 223 trios composed of one affected offspring and two healthy parents. Information on demographic characteristics, including gender and race, and family history of oral cleft and cancer were collected through direct interview of the patients and/or mothers (Additional file 1: Table S1). All patients were diagnosed independently and screened for the presence of associated anomalies or syndromes by the team of specialists from each center, and only patients with the nonsyndromic form were included. The NSCL $\pm \mathrm{P}$ was classified with the incisive foramen as reference [41].

The genomic DNA was isolated from buccal mucosa cells obtained by mouthwash with a $3 \%$ sucrose solution, using a salting-out protocol previously described [42]. SNPs, including rs16260, rs9929218, rs7186053 and rs4783573 in CDH1 and rs7591, rs7210356, rs4791171, rs11079571 and rs3923087 in AXIN2 (Table 1), were genotyped using the Taqman genotyping assay (assay-on-demand, Applied Biosystems). Genotyping analyses were randomly repeated in $10 \%$ of the samples, and the concordance rate was $100 \%$. These SNPs were selected based on their minor allele frequencies (www.ncbi.nlm.nih.gov) and because they were described as risk factors for oral cleft and breast and gastric cancer [29, 37, 39, 40, 43-46]. The study was approved by the ethics review board of each of the centers or hospitals affiliated with the collaborative study. Written informed consent was obtained from the parents or guardians and/or the participants.

For allele transmission analysis, the transmission disequilibrium test (TDT) was performed with the aid of

Table 1 Characteristics of the single-nucleotide polymorphisms (SNPS)

\begin{tabular}{llllll}
\hline SNP & Gene & Chromosome & Location & Position & Alleles \\
\hline rs16260 & CDH1 & 16 & promoter & $68,737,131$ & C/A \\
rs9929218 & CDH1 & 16 & intron & $68,787,043$ & G/A \\
rs7186053 & CDH1 & 16 & intron & $68,805,390$ & G/A \\
rs4783573 & CDH1 & 16 & intron & $68,806,685$ & G/A \\
rs7591 & AXIN2 & 17 & 3' UTR & $65,528,964$ & A/T \\
rs7210356 & AXIN2 & 17 & intron & $65,532,832$ & G/A \\
rs4791171 & AXIN2 & 17 & intron & $65,545,379$ & A/G \\
rs11079571 & AXIN2 & 17 & intron & $65,552,563$ & G/A \\
rs3923087 & AXIN2 & 17 & intron & $65,553,143$ & A/G \\
\hline
\end{tabular}

Risk alleles in bold 
the FBAT (Family Based Association Test) software. The haplotype-based analysis was conducted using the HBAT (Haplotype-Based Association Test) command in FBAT software. These tests are intended to verify the genotype-phenotype association from the unbalanced transmission of the alleles and haplotypes from healthy parents to affected children. The Z-score value measures the deviation from the null hypothesis, and positive $\mathrm{Z}$ score indicates that the allele is over-transmitted to the affected offspring (is a risk factor), whereas a negative Zscore indicates under-transmission to affected offspring (is a protective factor). The pair-wise linkage disequilibrium (LD) was estimated from the combined data of all trios calculating D' and $\mathrm{r}^{2}$ using the using Haploview software (v4.2). The $p$ value of $<0.05$ was considered statistically significant.

\section{Results}

Our results showed that the minor A allele of AXIN2 rs7210356 was significantly under-transmitted to patients with NSCL $\pm \mathrm{P}(p=0.01)$ (Table 2). HBAT analyses showed the C-G-A-A and A-G-A-G haplotypes formed by rs16260, rs9929218, rs7186053 and rs4783573 in $C D H 1$ were significantly transmitted from parents to the children with NSCL $\pm \mathrm{P} \quad(p=0.01$ and $p=0.008$, respectively) (Table 3 ). In $A X I N 2$ gene, the frequency of the T-G-G-A-G haplotype formed by rs7591, rs7210356, rs4791171, rs11079571 and rs3923087 SNPs was also under-transmitted to patients with NSCL \pm P $(p=0.03)$ (Table 4).

The LD pattern of the SNPs examined is displayed in Table 5. The LD values between $C D H 1$ SNPs were low, whereas AXIN2 SNPs rs7591, rs7210256 and rs4791171 were in complete linkage disequilibrium (rs7591 and rs7210356: $D^{\prime}=0.97$ and $r^{2}=0.10, \quad$ rs7591 and rs4791171: $D^{\prime}=0.93$ and $r^{2}=0.68, \quad$ rs7210356 and rs4791171: $D^{\prime}=0.95$ and $r^{2}=0.12$ ).

Table 2 Transmission disequilibrium test (TDT) of the singlenucleotide polymorphisms (SNPs) in nonsyndromic cleft lip with or without cleft palate (NSCL $\pm \mathrm{P})$ trios

\begin{tabular}{llllll}
\hline SNP & MAF & $\begin{array}{l}\text { Number of } \\
\text { families }\end{array}$ & T/NT & Z score & $p$ value \\
\hline rs16260 & 0.295 & 135 & $86 / 49$ & 1.00 & 0.31 \\
rs9929218 & 0.271 & 133 & $78 / 55$ & -0.46 & 0.64 \\
rs7186053 & 0.329 & 134 & $84 / 50$ & -0.98 & 0.32 \\
rs4783573 & 0.523 & 146 & $103 / 43$ & -1.39 & 0.16 \\
rs7591 & 0.543 & 154 & $121 / 33$ & 0.55 & 0.58 \\
rs7210356 & 0.081 & 54 & $34 / 20$ & -2.47 & $\mathbf{0 . 0 1}$ \\
rs4791171 & 0.616 & 139 & $118 / 21$ & 0.36 & 0.71 \\
rs11079571 & 0.215 & 99 & $50 / 49$ & -1.68 & 0.09 \\
rs3923087 & 0.606 & 136 & $116 / 20$ & 0.00 & 1.00 \\
\hline MAF: minor allel frequency & T/NT: transmission/non-transmission counts
\end{tabular}

MAF: minor allele frequency, T/NT: transmission/non-transmission counts
Table 3 Haplotype family-based association test for CDH1 rs16260, rs9929218, rs7186053 and rs4783573 performed using HBAT

\begin{tabular}{lllll}
\hline Haplotype $^{*}$ & $\begin{array}{l}\text { Number of } \\
\text { families }\end{array}$ & Frequency & Z score & $p$ value \\
\hline C-G-G-G & 119 & 0.336 & 0.73 & 0.46 \\
C-G-G-A & 94 & 0.216 & 0.80 & 0.42 \\
A-A-A-A & 82 & 0.185 & -0.71 & 0.47 \\
C-G-A-A & 42 & 0.064 & -2.48 & $\mathbf{0 . 0 1}$ \\
A-G-A-G & 22 & 0.032 & 2.66 & $\mathbf{0 . 0 0 8}$ \\
C-A-G-G & 17 & 0.031 & -0.07 & 0.94 \\
C-G-A-G & 21 & 0.029 & -1.20 & 0.23 \\
A-A-G-A & 20 & 0.025 & 0.64 & 0.52 \\
C-A-G-A & 16 & 0.018 & -0.96 & 0.34 \\
A-A-G-G & 12 & 0.015 & -0.14 & 0.88 \\
A-G-G-G & 10 & 0.013 & -0.31 & 0.76 \\
A-A-A-G & 12 & 0.010 & 1.12 & 0.26 \\
\hline Sequence 516260,15929218, s7186053 & &
\end{tabular}

*Sequence: rs16260, rs9929218, rs7186053 and rs4783573

\section{Discussion}

Although the exact environmental and genetic risk factors associated with $\mathrm{NSCL} \pm \mathrm{P}$ remains unclear, the understanding of the genetic mechanisms involved in this malformation are evolving. Interestingly, recent studies have demonstrated a relationship between congenital malformations and malignancies, and genetic alterations in $A X I N 2$ and $C D H 1$ are associated with both NSCL $\pm \mathrm{P}[37,39,47]$ and cancer of breast and gastric $[21,28,29,31-34]$. In this study we explored the clinical relevance of breast and gastric cancer-associated polymorphisms in $A X I N 2$ and $C D H 1$ with NSCL $\pm \mathrm{P}$ risk in the Brazilian population. Our results suggest that the AXIN2 rs7210356 SNP is associated with the occurrence of NSCL $\pm \mathrm{P}$ in the investigated population. This SNP was associated with breast cancer risk in premenopausal

Table 4 Haplotype family-based association test for AXIN2 rs7591, rs7210356, rs4791171, rs11079571 and rs3923087 performed using HBAT

\begin{tabular}{llccc}
\hline Haplotype $^{*}$ & $\begin{array}{l}\text { Number of } \\
\text { families }\end{array}$ & Frequency & Z score & $p$ value \\
\hline T-G-G-G-G & 96 & 0.486 & 1.45 & 0.15 \\
A-G-A-G-A & 77 & 0.158 & 0.75 & 0.45 \\
A-G-A-A-A & 62 & 0.121 & 0.02 & 0.98 \\
A-G-G-G-G & 30 & 0.052 & 0.35 & 0.73 \\
A-A-A-A-A & 17 & 0.031 & -1.89 & 0.06 \\
T-G-G-G-G & 20 & 0.030 & 0.15 & 0.88 \\
A-A-A-G-G & 15 & 0.029 & -0.37 & 0.71 \\
A-G-A-G-G & 14 & 0.019 & -1.39 & 0.16 \\
T-G-G-A-G & 12 & 0.016 & -2.08 & $\mathbf{0 . 0 3}$ \\
A-G-G-A-G & 11 & 0.013 & 0.39 & 0.69 \\
\hline${ }^{*}$ Sequence: rs7591, rs7210356, rs4791171, rs11079571 and rs3923087 &
\end{tabular}

"Sequence: rs7591, rs7210356, rs4791171, rs11079571 and rs3923087 
Table 5 Linkage disequilibrium analysis of the $\mathrm{CDH}$ ( $\mathrm{A}$ ) and AXIN2 (B) SNP. $D^{\prime}$ coefficient is above the diagonal and $r^{\prime}$ is below diagonal

\begin{tabular}{lllllll}
\hline A & & & & & \\
& rs16260 & rs9929218 & rs7186053 & rs4783573 & \\
rs16260 & - & 0.77 & 0.69 & 0.49 & \\
rs9929218 & 0.55 & - & 0.57 & 0.59 & \\
rs7186053 & 0.41 & 0.26 & - & 0.48 & \\
rs4783573 & 0.09 & 0.12 & 0.10 & - & \\
B & & & & & \\
& rs7591 & rs7210356 & rs4791171 & rs11079571 & rs3923087 \\
rs7591 & - & 0.97 & 0.93 & 0.78 & 0.77 \\
rs7210356 & 0.10 & - & 0.95 & 0.35 & 0.27 \\
rs4791171 & 0.68 & 0.12 & - & 0.74 & 0.79 \\
rs11079571 & 0.20 & 0.04 & 0.23 & - & 0.86 \\
rs3923087 & 0.47 & 0.01 & 0.61 & 0.31 & - \\
\hline
\end{tabular}

but not in postmenopausal women [29]. The impact of the rs7210356 polymorphism in lip and palate development is unclear and our findings are of interest especially to understand this association. Haplotype analysis showed that five SNPs in AXIN2 (rs7591, rs7210356, rs4791171, rs11079571 and rs3923087) were associated with occurrence of NSCL \pm P. Previously studies revealed that the both rs7591 and rs3923087 were associated with $\mathrm{NSCL} \pm \mathrm{P}$ and tooth agenesis $[37,46]$.

CDH1 haplotypes composed by rs16260, rs 9929218 , rs7186053 and rs4783573 were associated with NSCL \pm $\mathrm{P}$ in our study population. Many reports showed that rs16260 is associated with the development of gastric cancer $[45,48]$, but it is controversial its association with craniofacial development [39, 40]. Similarly, rs9929218 was shown to have a borderline association with unilateral NSCL/P in Brazilian population [37] as well as the haplotype composed of rs9929218, rs7186053, rs4783573 and rs16958383 to NSCL/P in the population of Warsaw [40]. CDH1 plays a key role in cell adhesion, which is vital to normal development, including craniofacial morphogenesis and palatal fusion [49]. Thus, further examination of haplotypes in $C D H 1$ gene, including rs16260, rs9929218, rs7186053 and rs4783573, is needed to identify the molecular relevant causes.

\section{Conclusions}

In summary, little is known about the relationship between AXIN2 and CDH1 genes and oral clefts in humans. In the present study identified one SNP and one haplotype in AXIN2 gene and two haplotypes in $C D H 1$ gene significantly associated with $\mathrm{NSCL} \pm \mathrm{P}$ susceptibility in Brazilian population. Except the C-G-A-A haplotype formed by rs16260, rs9929218, rs7186053 and rs4783573 in $C D H 1$ gene which was associated with increased risk of NSCL $\pm \mathrm{P}$, the others haplotypes in AXIN2 and CDH1 genes, as well as the rs7210356 allele alone, were associated in a protective manner to NSCL \pm P. Though, the population size in our study is small and the significant results need to be confirmed in larger groups with known family history of breast and gastric cancer to better understand the interactions between $A X I N 2$ and $C D H 1$ genes in the development of NSCL $\pm \mathrm{P}$.

\section{Additional file}

Additional file 1: Table S1. Clinical and epidemiological characteristics of patients with nonsyndromic cleft lip with or without cleft palate. (DOCX $14 \mathrm{~kb})$

\begin{abstract}
Abbreviations
AXIN2: Axis inhibition protein 2; CDH1: Cadherin-1; FBAT: Family based association test; HBAT: Haplotype-based association test; MAF: Minor allele frequency; NSCL $\pm P$ : Nonsyndromic cleft lip with or without cleft palate; NSCLO: Nonsyndromic cleft lip only; NSCLP: Nonsyndromic cleft lip and palate; NSCPO: Nonsyndromic cleft palate only; OR: Odds ratio; SNP: Single nucleotide polymorphism; T/NT: Transmission/non-transmission counts;

TDT: Transmission disequilibrium test
\end{abstract}

\section{Acknowledgments}

The authors thank all the study subjects and research staff who participated in this work.

\section{Funding}

This work was supported by grants from Research Support Foundation of Minas Gerais - FAPEMIG, National Council for Scientific and Technological Development - CNPq, Coordination of Improvement of High Education Personnel (CAPES) and Procad/Casadinho.

Availability of data and materials

All data and materials supporting the conclusions of this article are included within the article and its Additional file 1: Table S1.

\section{Authors' contributions}

RC and HMJ designed and supervised the study. RAM, SNA, DRM, MSO, SRR, DCP, HSM and VOD recruited participants, analyzed and interpreted the data, drafted and revised the manuscript; RAM and EMF performed laboratory experiments, analyzed and interpreted the data, assisted with drafting the manuscript. All authors have read and approved the final version of the manuscript.

\section{Competing interests}

The authors declare that they have no competing interests.

\section{Consent for publication}

Not applicable.

Ethics approval and consent to participate

Participants were recruited from the Center for Rehabilitation of Craniofacial Anomalies (located in the Southeastern region of Brazil), Association of Carrier of Lip and Palate Cleft-APOFILAB (located in the South of Brazil), University Hospital of Lauro Wanderley-HULW and Santo Antonio Hospital, which are located in the Northeastern region. This study was approved by the institutional review board of each participating hospitals. Written consents were obtained from each participant.

\section{Publisher's Note}

Springer Nature remains neutral with regard to jurisdictional claims in published maps and institutional affiliations. 


\section{Author details}

'Department of Oral Diagnosis, Dental School, State University of Campinas, Piracicaba, São Paulo, Brazil. ${ }^{2}$ Stomatology Clinic, Dental School, State University of Montes Claros, Montes Claros, Minas Gerais, Brazil. ${ }^{3}$ School of Dentistry, Federal University of Juiz de Fora, Governador Valadares, Minas Gerais, Brazil. ${ }^{4}$ Center for Rehabilitation of Craniofacial Anomalies, University of José Rosário Vellano, Alfenas, Minas Gerais, Brazil. ${ }^{5}$ Department of Basic Science, Bahiana School of Medicine and Public Health, Salvador, Bahia, Brazil. ' ${ }^{6}$ Molecular Biology Departament, Federal University of Paraíba, João Pessoa, Paraíba, Brazil. 'Department of Physiotherapy, State University of Western Paraná, Cascavel, Paraná, Brazil.

Received: 4 August 2016 Accepted: 3 March 2017 Published online: 04 April 2017

\section{References}

1. Dixon MJ, Marazita ML, Beaty TH, Murray JC. Cleft lip and palate: understanding genetic and environmental influences. Nat Rev Genet. 2011;12(3):167-78.

2. Marazita ML, Lidral AC, Murray JC, Field LL, Maher BS, Goldstein McHenry T, Cooper ME, Govil M, Daack-Hirsch S, Riley B, Jugessur A, Felix T, Morene L, Mansilla MA, Vieira AR, Doheny K, Pugh E, Valencia-Ramirez C, Arcos-Burgos M. Genome scan, fine-mapping, and candidate gene analysis of nonsyndromic cleft lip with or without cleft palate reveals phenotype-specific differences in linkage and association results. Hum Hered. 2009;68(3):151-70.

3. Meng L, Bian Z, Torensma R, Von den Hoff JW. Biological mechanisms in palatogenesis and cleft palate. J Dent Res. 2009:88(1):22-33.

4. Mangold E, Ludwig KU, Nothen MM. Breakthroughs in the genetics of orofacial clefting. Trends Mol Med. 2011;17(12):725-33.

5. Harville EW, Wilcox AJ, Lie RT, Vindenes H, Abyholm F. Cleft lip and palate versus cleft lip only: are they distinct defects? Am J Epidemiol. 2005;162(5):448-53.

6. Grosen D, Chevrier C, Skytthe A, Bille C, Molsted K, Sivertsen A, Murray JC, Christensen K. A cohort study of recurrence patterns among more than 54,000 relatives of oral cleft cases in Denmark: support for the multifactorial threshold model of inheritance. J Med Genet. 2010:47(3):162-8.

7. Murthy J, Bhaskar L. Current concepts in genetics of nonsyndromic clefts. Indian J Plast Surg. 2009:42(1):68-81.

8. Machado RA, Moreira HS, de Aquino SN, Martelli-Junior $\mathrm{H}$, de Almeida Reis SR, Persuhn DC, Wu T, Yuan Y, Coletta RD. Interactions between RAD51 rs1801321 and maternal cigarette smoking as risk factor for nonsyndromic cleft lip with or without cleft palate. Am J Med Genet A. 2016;170(2):536-9.

9. Wu T, Schwender H, Ruczinski I, Murray JC, Marazita ML, Munger RG Hetmanski JB, Parker MM, Wang P, Murray T, Taub M, Li S, Redett RJ, Fallin MD, Liang KY, Wu-Chou YH, Chong SS, Yeow V, Ye X, Wang H, Huang S, Jabs EW, Shi B, Wilcox AJ, Jee SH, Scott AF, Beaty TH. Evidence of gene-environment interaction for two genes on chromosome 4 and environmental tobacco smoke in controlling the risk of nonsyndromic cleft palate. PLoS One. 2014;9(2):e88088.

10. James A, Oluwatosin B, Njideka G, Babafemi BOG, Olufemi D, Leo R, Folorunso I, Phylis OO. Cleft palate in hiv-exposed newborns of mothers on highly active antiretroviral therapy. Oral Surg. 2014;7 Suppl 1:102-6.

11. Figueiredo JC, Ly S, Magee KS, Ihenacho U, Baurley JW, Sanchez-Lara PA Brindopke F, Nguyen TH, Nguyen V, Tangco MI, Giron M, Abrahams T, Jang G, Vu A, Zolfaghari E, Yao CA, Foong A, DeClerk YA, Samet JM, Magee W. Parental risk factors for oral clefts among Central Africans, Southeast Asians, and Central Americans. Birth Defects Res A Clin Mol Teratol. 2015:103(10):863-79.

12. Yuan Q, Blanton SH, Hecht JT. Genetic causes of nonsyndromic cleft lip with or without cleft palate. Adv Otorhinolaryngol. 2011;70:107-13.

13. Mehrotra D. Genomic expression in non syndromic cleft lip and palate patients: a review. J Oral Biol Craniofac Res. 2015;5(2):86-91.

14. Taioli E, Ragin C, Robertson L, Linkov F, Thurman NE, Vieira AR. Cleft lip and palate in family members of cancer survivors. Cancer Invest. 2010;28(9):958-62

15. Jindal A, Vieira AR. Family history of cleft lip and palate in subjects diagnosed with leukemia. Am J Med Genet A. 2012;158A(3):678-9.

16. Zhu JL, Basso O, Hasle H, Winther JF, Olsen JH, Olsen J. Do parents of children with congenital malformations have a higher cancer risk? a nationwide study in Denmark. Br J Cancer. 2002;87(5):524-8.

17. Vieira AR, Khaliq S, Lace B. Risk of cancer in relatives of children born with isolated cleft lip and palate. Am J Med Genet A. 2012;158A(6):1503-4.
18. Goncalves E, Martelli DR, Coletta RD, Vieira AR, Caldeira AP, Martelli Jr H. Risk of leukemia in first degree relatives of patients with nonsyndromic cleft lip and palate. Braz Oral Res. 2014;28(1):1-3.

19. Frebourg T, Oliveira C, Hochain P, Karam R, Manouvrier S, Graziadio C Vekemans M, Hartmann A, Baert-Desurmont S, Alexandre C, Lejeune Dumoulin S, Marroni C, Martin C, Castedo S, Lovett M, Winston J, Machado JC, Attié T, Jabs EW, Cai J, Pellerin P, Triboulet JP, Scotte M, Le Pessot F, Hedouin A, Carneiro F, Blayau M, Seruca R. Cleft lip/palate and CDH1/Ecadherin mutations in families with hereditary diffuse gastric cancer. J Med Genet. 2006;43(2):138-42.

20. Cavallaro U, Dejana E. Adhesion molecule signalling: not always a sticky business. Nat Rev Mol Cell Biol. 2011;12(3):189-97.

21. Li S, Wang C, Liu X, Hua S. The roles of AXIN2 in tumorigenesis and epigenetic regulation. Fam Cancer. 2015;14(2):325-31.

22. Mani $P$, Jarrell A, Myers J, Atit R. Visualizing canonical Wnt signaling during mouse craniofacial development. Dev Dyn. 2010;239(1):354-63.

23. Chiquet BT, Blanton SH, Burt A, Ma D, Stal S, Mulliken JB, Hecht JT. Variation in WNT genes is associated with non-syndromic cleft lip with or without cleft palate. Hum Mol Genet. 2008;17(14):2212-8.

24. Lu YP, Han WT, Liu Q, Li JX, Li ZJ, Jiang M, Xu W. Variations in WNT3 gene are associated with incidence of non-syndromic cleft lip with or without cleft palate in a northeast Chinese population. Genet Mol Res. 2015;14(4):12646-53.

25. Galamb O, Kalmár A, Péterfia B, Csabai I, Bodor A, Ribli D, Krenács T, Patai ÁV, Wichmann B, Barták BK, Tóth K, Valcz G, Spisák S, Tulassay Z, Molnár B. Aberrant DNA methylation of WNT pathway genes in the development and progression of CIMP-negative colorectal cancer. Epigenetics. 2016; 11(8):588-602.

26. Chan DW, Mak CS, Leung TH, Chan KK, Ngan HY. Down-regulation of Sox7 is associated with aberrant activation of Wnt/b-catenin signaling in endometrial cancer. Oncotarget. 2012;3(12):1546-56.

27. Baarsma HA, Konigshoff M, Gosens R. The WNT signaling pathway from ligand secretion to gene transcription: molecular mechanisms and pharmacological targets. Pharmacol Ther. 2013;138(1):66-83.

28. Wang SH, Li N, Wei Y, Li QR, Yu ZP. beta-catenin deacetylation is essential for WNT-induced proliferation of breast cancer cells. Mol Med Rep. 2014;9(3):973-8.

29. Wang X, Goode EL, Fredericksen ZS, Vierkant RA, Pankratz VS, Liu-Mares W, Rider DN, Vachon CM, Cerhan JR, Olson JE, Couch FJ. Association of genetic variation in genes implicated in the beta-catenin destruction complex with risk of breast cancer. Cancer Epidemiol Biomarkers Prev. 2008;17(8):2101-8.

30. Paredes J, Figueiredo J, Albergaria A, Oliveira P, Carvalho J, Ribeiro AS, Caldeira J, Costa AM, Simões-Correia J, Oliveira MJ, Pinheiro H, Pinho SS, Mateus R, Reis CA, Leite M, Fernandes MS, Schmitt F, Carneiro F, Figueiredo C, Oliveira C, Seruca R. Epithelial E- and P-cadherins: role and clinical significance in cancer. Biochim Biophys Acta. 2012;1826(2):297-311.

31. Liu X, Chu KM. E-cadherin and gastric cancer: cause, consequence, and applications. Biomed Res Int. 2014;2014:637308.

32. Jiang B, Zhu K, Shao H, Bao C, Ou J, Sun W. Lack of association between the $\mathrm{CDH1}$ polymorphism and gastric cancer susceptibility: a meta-analysis. Sci Rep. 2015;5:7891.

33. Li YL, Tian Z, Zhang JB, Fu BY. CDH1 promoter polymorphism and stomach cancer susceptibility. Mol Biol Rep. 2012;39(2):1283-6.

34. van der Post RS, Vogelaar IP, Carneiro F, Guilford P, Huntsman D, Hoogerbrugge N, Caldas C, Schreiber KE, Hardwick RH, Ausems MG, Bardram L, Benusiglio PR, Bisseling TM, Blair V, Bleiker E, Boussioutas A, Cats A, Coit D, DeGregorio L, Figueiredo J, Ford JM, Heijkoop E, Hermens R, Humar B, Kaurah P, Keller G, Lai J, Ligtenberg MJ, O'Donovan M, Oliveira C, Pinheiro H, Ragunath K, Rasenberg E, Richardson S, Roviello F, Schackert H, Seruca R, Taylor A, Ter Huurne A, Tischkowitz M, Joe ST, van Dijck B, van Grieken NC, van Hillegersberg R, van Sandick JW, Vehof R, van Krieken JH, Fitzgerald RC. Hereditary diffuse gastric cancer: updated clinical guidelines with an emphasis on germline $\mathrm{CDH} 1$ mutation carriers. J Med Genet. 2015:52(6):361-74

35. Han Y, Zhou L, Ma L, Li D, Xu M, Yuan H, Ma J, Zhang W, Jiang H, Wu Y, Wang L, Pan Y. The axis inhibition protein 2 polymorphisms and nonsyndromic orofacial clefts susceptibility in a Chinese Han population. J Oral Pathol Med. 2014:43(7):554-60.

36. Letra A, Bjork B, Cooper ME, Szabo-Rogers H, Deleyiannis FW, Field LL, Czeizel AE, Ma L, Garlet GP, Poletta FA, Mereb JC, Lopez-Camelo JS, Castilla EE, Orioli IM, Wendell S, Blanton SH, Liu K, Hecht JT, Marazita ML, Vieira AR, 
Silva RM. Association of AXIN2 with non-syndromic oral clefts in multiple populations. J Dent Res. 2012;91(5):473-8.

37. Letra A, Menezes R, Granjeiro JM, Vieira AR. AXIN2 and CDH1 polymorphisms, tooth agenesis, and oral clefts. Birth Defects Res A Clin Mol Teratol. 2009;85(2):169-73.

38. Bureau A, Parker MM, Ruczinski I, Taub MA, Marazita ML, Murray JC, Mangold E, Noethen MM, Ludwig KU, Hetmanski JB, Bailey-Wilson JE, Cropp CD, Li Q, Szymczak S, Albacha-Hejazi H, Alqosayer K, Field LL, Wu-Chou YH, Doheny KF, Ling $\mathrm{H}$, Scott AF, Beaty TH. Whole exome sequencing of distant relatives in multiplex families implicates rare variants in candidate genes for oral clefts. Genetics. 2014;197(3):1039-44.

39. Song $\mathrm{Y}$, Zhang S. Association of $\mathrm{CDH} 1$ promoter polymorphism and the risk of non-syndromic orofacial clefts in a Chinese Han population. Arch Ora Biol. 2011;56(1):68-72.

40. Hozyasz KK, Mostowska A, Wojcicki P, Lasota A, Offert B, Balcerek A, DuninWilczyńska I, Jagodziński PP. Nucleotide variants of the cancer predisposing gene $\mathrm{CDH} 1$ and the risk of non-syndromic cleft lip with or without cleft palate. Fam Cancer. 2014;13(3):415-21.

41. Spina V, Psillakis JM, Lapa FS, Ferreira MC. Classification of cleft lip and cleft palate. Suggested changes. Rev Hosp Clin Fac Med Sao Paulo. 1972;27(1):5-6.

42. Aidar M, Line SR. A simple and cost-effective protocol for DNA isolation from buccal epithelial cells. Braz Dent J. 2007;18(2):148-52.

43. Alanazi MS, Parine NR, Shaik JP, Alabdulkarim HA, Ajaj SA, Khan Z. Association of single nucleotide polymorphisms in Wnt signaling pathway genes with breast cancer in Saudi patients. PLoS One. 2013;8(3):e59555.

44. Jing $H$, Dai F, Zhao C, Yang J, Li L, Kota P, Mao L, Xiang K, Zheng C, Yang J. Association of genetic variants in and promoter hypermethylation of $\mathrm{CDH} 1$ with gastric cancer: a meta-analysis. Medicine (Baltimore). 2014;93(19):e107.

45. Zhan Z, Wu J, Zhang JF, Yang YP, Tong S, Zhang CB, Li J, Yang XW, Dong W. $\mathrm{CDH} 1$ gene polymorphisms, plasma $\mathrm{CDH} 1$ levels and risk of gastric cancer in a Chinese population. Mol Biol Rep. 2012;39(8):8107-13.

46. Mostowska A, Hozyasz KK, Wojcicki P, Lasota A, Dunin-Wilczynska I, Jagodzinski PP. Association of DVL2 and AXIN2 gene polymorphisms with cleft lip with or without cleft palate in a Polish population. Birth Defects Res A Clin Mol Teratol. 2012;94(11):943-50.

47. Menezes R, Marazita ML, Goldstein McHenry T, Cooper ME, Bardi K, Brandon C, Letra A, Martin RA, Vieira AR. AXIS inhibition protein 2, orofacial clefts and a family history of cancer. J Am Dent Assoc. 2009;140(1):80-4.

48. Al-Moundhri MS, Al-Khanbashi M, Al-Kindi M, Al-Nabhani M, Burney IA Al-Farsi A, Al-Bahrani B. Association of E-cadherin ( $\mathrm{CDH} 1)$ gene polymorphisms and gastric cancer risk. World J Gastroenterol. 2010;16(27):3432-6.

49. Kerrigan JJ, Mansell JP, Sengupta A, Brown N, Sandy JR. Palatogenesis and potential mechanisms for clefting. J R Coll Surg Edinb. 2000;45(6):351-8.

\section{Submit your next manuscript to BioMed Central and we will help you at every step:}

- We accept pre-submission inquiries

- Our selector tool helps you to find the most relevant journal

- We provide round the clock customer support

- Convenient online submission

- Thorough peer review

- Inclusion in PubMed and all major indexing services

- Maximum visibility for your research

Submit your manuscript at www.biomedcentral.com/submit

) Biomed Central 